\title{
Ethnobotanical Study of Medicinal Plants Used by the Tribes of Nalamalai Forests
}

\author{
Yirivinti Hayagre eva Dinakar* \\ Department of pharmacognosy, Creative Educational Society's college of pharmacy, Kurnool, Andhra Pradesh. \\ *Corresponding Author: Yirivinti Hayagreeva Dinakar, Department of pharmacognosy, Creative \\ Educational Society's college of pharmacy, Kurnool, Andhra Pradesh.
}

\begin{abstract}
India is known for its rich tradition in all aspects and in medicines too. An Ethnobotanical study was performed in some parts of Nallamala forests and the information regarding traditional medicines and their way of usage was collected along with dose etc with the help of standard questionnaire and some information is also taken from internet sources.The information for treating 20 ailments were collected which include diabetes, syphilis, insect bites etc. The plants belong to wide range offamilies ap proximately of 17 families. Of all the information on plants collected leaves are most widely used part and for most of the diseases the juice of the leaves are given orally, while some include application on skin, application on eyes etc.The current study deals with the uses of different traditional medicine by the tribals of nallamala forest for treating different ailments
\end{abstract}

Keywords: Ethnobotanical study, Ailments, Nalamalai forest, Traditional medicine, Plant species, etc.

\section{INTRODUCTION}

India has nearly 4,70,000 plant species. Of these 50,000 are limited to only one region. More than 8000 plant species are used as tribal medicine in india .For village medicine 5000 species, 700 plant species are used in Unani, in Ayurvedic medicine 800 plant species are used .From the above information the importance of tribal medicine can be understood.[4]

The nallamala forest extends over Nellore, Guntur, Kurnool, kadapa, chittoor districts of Andhra Pradesh and some parts of telangana, Karnataka. The highest peak of nallamala forest is the bairani konda also known as sikhareshwaram. The Nallamala forest have mostly warm to hot climate throughout the year. It has an average rainfall of $90 \mathrm{~cm}$ [2]. The soil of the nallamala forest in the Kurnool region is mainly the calcareous shale [3]. The geographical area of the 17,658 sq.km. The main tribal population of this region include the Chenchus, Lambadas, Sugalis, Yerukalas,etc[1]. Others are also different categories of chenchus like Mandli, Pitta, Kokala, Kudumula, Dhamsani etc. Srisailam, Ahobilam etc are some of the pilgrimages in this nallamala region. The main reason for the abundance of the herbal or medicinal plants in this region is the prolific soil, satisfying climate and topography [3].

\section{Materials AND Methods}

An ethnobotanical study was performed in the nallamala forest of Kurnool region in Andhra Pradesh. A standard questionnaire was prepared before the study. The tribals of the area were enquired about the various traditional medicine used by them for treating various ailments which also include medical experts. The various ailments in the current study include arthritis, gonnorhea, snake bites, diabetes, dandruff, malaria, kidney stones, pimples, sprains etc. The vernacular names were collected along with the disease for which it is used and the part of the plant used is also collected and its usage.

\section{RES ULTS AND DISCUSSION}

With the aid of standard questionnaire a study was done in the Nallamala region and the information regarding various plants used for treating different ailments was collected along with the part used, the family to which the plant belong, its usage ,and to which disease it is used for and some information is collected from internet sources. The information for treating 20 ailments was collected. The various ailments in the current study include arthritis, gonnorhea, snake bites, diabetes, dandruff, malaria, kidney stones, pimples, sprains etc. The plants used belong to families of fabaceae, malvaceae, loganiaceae, anacardiaceae, annonaceae, combretaceae, euphorbiaceae, caesalpiniaceae. 
Of the above plants, 4 of them belong to loganiaceae family, 2 belong to fabaceae family and one plant for each of all families .For most of the diseases leaves of the plant are used, and for some roots, bark, seeds and fruits are also used. The examples of the plants include Phillanthus amarus for diabetes, Butea monosperma for jaundice, Benincasa hispida for dandruff, and Andrographus paniculata for malaria fever, etc.

\section{Conclusion}

From the above study the knowledge about the various traditional medicinal plants used for treating various ailments was gained. Use of herbal medicines has been followed since ages but the development of modern or allopathic drugs made the use of herbal plants less priority. But the herbal plants are still been potently used for treating various diseases as observed in the nalamalai forests.

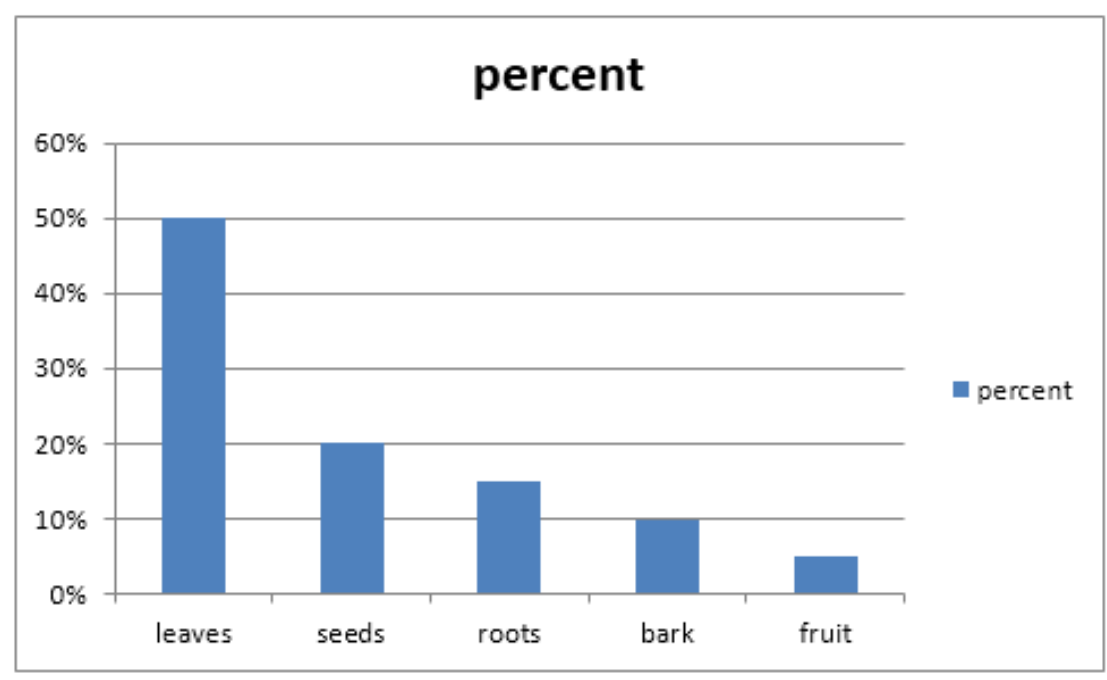

Fig1. A bar graph showing various parts of the plants and their percents in the current study

Table1. Number of species collected belonging to various families

\begin{tabular}{|l|l|}
\hline FAMILY & $\begin{array}{l}\text { NUMBER OF PLANTS BELONGING TO THE } \\
\text { FAMILY }\end{array}$ \\
\hline ANACARDIACEAE & 1 \\
\hline EUPHORBIACEAE & 1 \\
\hline AMARANTHACEAE & 1 \\
\hline MALVACEAE & 1 \\
\hline LOGANIACEAE & 4 \\
\hline CAESSALPINIACEAE & 1 \\
\hline COMBRETACEAE & 1 \\
\hline ARECACEAE & 1 \\
\hline ANNONACEAE & 1 \\
\hline CUCURBITACEAE & 1 \\
\hline ACANTHACEAE & 1 \\
\hline FABACEAE & 2 \\
\hline PAPAVERACEAE & 1 \\
\hline LAMINACEAE & 1 \\
\hline SAXIFRAGACEAE & 1 \\
\hline
\end{tabular}

Table2. A brief description of various plants their vernacular name, scientific name, family, part of the plant used, disease and its usage.

\begin{tabular}{|l|l|l|l|l|l|}
\hline Species & $\begin{array}{l}\text { Vernacular } \\
\text { name }\end{array}$ & Family & $\begin{array}{l}\text { Treating } \\
\text { disease }\end{array}$ & $\begin{array}{l}\text { Part } \\
\text { used }\end{array}$ & Usage \\
\hline $\begin{array}{l}\text { 1.Lannea } \\
\text { coromandalica }\end{array}$ & $\begin{array}{l}\text { Pedda } \\
\text { barnika }\end{array}$ & Anacardiaceae & $\begin{array}{l}\text { Mouth } \\
\text { infections }\end{array}$ & Leaves & $\begin{array}{l}\text { Leaves are given in a juice } \\
\text { form 5 times a day }\end{array}$ \\
\hline $\begin{array}{l}\text { 2.Phillanthus } \\
\text { amarus }\end{array}$ & Nela oosari & Euphorbiaceae & Diabetes & Leaves & $\begin{array}{l}\text { Nelaoosari, pepper, gymnema } \\
\text { sylvestre are powdered and } \\
\text { taken with honey. }\end{array}$ \\
\hline $\begin{array}{l}\text { 3.Gomphrena } \\
\text { serrata }\end{array}$ & $\begin{array}{l}\text { Chiru } \\
\text { nallintha }\end{array}$ & Amaranthaceae & Gonnorhea & Roots & $\begin{array}{l}\text { Roots are triturated and } \\
\text { filtered. the juice is applied } \\
\text { with cotton. }\end{array}$ \\
\hline
\end{tabular}


Ethnobotanical Study of Medicinal Plants Used by the Tribes of Nalamalai Forests

\begin{tabular}{|c|c|c|c|c|c|}
\hline $\begin{array}{l}\text { 4.Abtilon } \\
\text { indicum }\end{array}$ & $\begin{array}{l}\text { Thuthuru } \\
\text { benda }\end{array}$ & Malvaceae & $\begin{array}{l}\text { Menstrual } \\
\text { problems }\end{array}$ & Roots & $\begin{array}{l}\text { Roots are dried and used until } \\
\text { cure. }\end{array}$ \\
\hline $\begin{array}{l}\text { 5.Strychnus } \\
\text { potatorum }\end{array}$ & Chilla ginja & Loganiaceae & Insect bite & seeds & $\begin{array}{l}\text { Seeds are dipped in water and } \\
\text { pressed on wound }\end{array}$ \\
\hline $\begin{array}{l}\text { 6.Caes elpinia } \\
\text { bonduc }\end{array}$ & Billa gacha & Caeselpiniaceae & Arthritis & Roots & $\begin{array}{l}\text { Bonduc and forest garlic are } \\
\text { mixed and applied in legs. }\end{array}$ \\
\hline $\begin{array}{l}\text { 7.Terminalia } \\
\text { arjuna }\end{array}$ & $\begin{array}{l}\text { Naramamidi } \\
\text { chekka }\end{array}$ & Combretaceae & Sprains & Bark & $\begin{array}{l}\text { Latex is taken and made juice } \\
\text { and used for } 15 \text { days. }\end{array}$ \\
\hline 8.Arecaceaae & Eetha & Arecaceae & $\begin{array}{l}\text { Throat } \\
\text { infection }\end{array}$ & Leaves & $\begin{array}{l}\text { Juice is extracted from leaves } \\
\text { and used till cure. }\end{array}$ \\
\hline $\begin{array}{l}\text { 9.Annona } \\
\text { reticulata }\end{array}$ & Sitapalam & Annonaceae & Dandruff & Leaves & $\begin{array}{l}\text { Annona and palm leaves are } \\
\text { mixed and boiled and oil is } \\
\text { applied. }\end{array}$ \\
\hline $\begin{array}{l}\text { 10.Corollocarpus } \\
\text { epigius }\end{array}$ & $\begin{array}{l}\text { Naga } \\
\text { dhonda }\end{array}$ & Cucurbitaceae & $\begin{array}{l}\text { Kidney } \\
\text { stones }\end{array}$ & Leaves & $\begin{array}{l}\text { Leaves are taken dried, } \\
\text { powdered and taken with } \\
\text { water. }\end{array}$ \\
\hline $\begin{array}{l}\text { 11.Andrographus } \\
\text { paniculata }\end{array}$ & Nelavemu & Acanthaceae & $\begin{array}{l}\text { Malaria } \\
\text { fever }\end{array}$ & leaves & $\begin{array}{l}\text { Andrographus and pepper and } \\
\text { garlic paste is made and used. }\end{array}$ \\
\hline $\begin{array}{l}\text { 12.Butea } \\
\text { monosperma }\end{array}$ & $\begin{array}{l}\text { Moduga } \\
\text { aaku }\end{array}$ & Fabaceae & Jaundice & leaves & $\begin{array}{l}\text { Gum is taken and applied on } \\
\text { eyes for every night. }\end{array}$ \\
\hline $\begin{array}{l}\text { 13.Strychnus } \\
\text { nuxvomica }\end{array}$ & $\begin{array}{l}\text { Visha } \\
\text { moosti }\end{array}$ & Loganaceae & $\begin{array}{l}\text { Skin } \\
\text { problems }\end{array}$ & Seeds & $\begin{array}{l}\text { Seeds are powdered and taken } \\
2 \text { times a day. }\end{array}$ \\
\hline $\begin{array}{l}\text { 14.Strychnus } \\
\text { potatorum }\end{array}$ & Chilla ginja & Loganiaceae & Pimples & Seeds & $\begin{array}{l}\text { Paste is taken and applied } 2 \\
\text { times a day. }\end{array}$ \\
\hline $\begin{array}{l}\text { 15.Benincasa } \\
\text { hispida }\end{array}$ & $\begin{array}{l}\text { Gumadi } \\
\text { kaya }\end{array}$ & Cucurbitaceae & Dandruff & Fruit & Paste is taken and applied. \\
\hline $\begin{array}{l}\text { 16.Papaver } \\
\text { sominiferum }\end{array}$ & Nallamandu & Papeveraceae & Sedative & latex & Used at night time. \\
\hline $\begin{array}{l}\text { 17.Crotolaria } \\
\text { verrucosa }\end{array}$ & $\begin{array}{l}\text { Thella } \\
\text { eswari }\end{array}$ & Fabaceae & Snake bite & Leaves & $\begin{array}{l}\text { Leaves are taken and made } \\
\text { paste and applied on wounds. }\end{array}$ \\
\hline $\begin{array}{l}\text { 18.Leucas } \\
\text { linifolia }\end{array}$ & Thumi tree & Laminaceae & Wounds & Leaves & $\begin{array}{l}\text { Leaves are taken and juice is } \\
\text { made and applied on wounds. }\end{array}$ \\
\hline $\begin{array}{l}\text { 19.Strychnus } \\
\text { nuxvomica }\end{array}$ & $\begin{array}{l}\text { Visha } \\
\text { moosti }\end{array}$ & Loganiaceae & Ringworm & Seeds & $\begin{array}{l}\text { Seeds are powdered and } \\
\text { taken. }\end{array}$ \\
\hline $\begin{array}{l}\text { 20.Bergenia } \\
\text { ciliata }\end{array}$ & $\begin{array}{l}\text { kondapindi } \\
\text { leaves }\end{array}$ & Saxotragaceae & $\begin{array}{l}\text { Kidney } \\
\text { stones }\end{array}$ & Leaves & $\begin{array}{l}\text { Powdered and taken with } \\
\text { water. }\end{array}$ \\
\hline
\end{tabular}

\section{REFERENCES}

[1] B.v Ramana naidu., D .Haribabu Rao., P.Subramanyam., C.Prabhakar raju., D.Jayasimha Rayalu., Ethnobotanical study of medicinal plants used by the tribes in nallamala forest area of Kurnool district,Andhra Pradesh ,int. j. plant ,animal and env sci 2(4), 72 (2012)

[2] https://en.wikipedia.org/wiki/Nallamala_Hills .

[3] https://www.deccanchronicle.com/nation/in-other-news/131217/ethnic-medicine-mainstay-of-tribes-innallamala-area.html.

[4] Allam vijay bhaskar reddy and kathula ram reddy, Andhra Pradesh girijana vaidyamrutham , $1^{\text {st }}$ ed. Hyderabad, Tribal cultural research and training institute ,2012,ch.0,pp.vii

Citation: Y. Dinakar, "Ethnobotanical Study of Medicinal Plants Used by the Tribes of Nalamalai Forests", International Journal of Medicinal Plants and Natural Products (IJMPNP), vol. 4, no. 1, pp. 19-21, 2018. http://dx.doi.org/10.20431/2454-7999.0401004

Copyright: () 2018 Authors. This is an open-access article distributed under the terms of the Creative Commons Attribution License, which permits unrestricted use, distribution, and reproduction in any medium, provided the original author and source are credited. 